\title{
IQCK wt Allele
}

National Cancer Institute

\section{Source}

National Cancer Institute. IQCK wt Allele. NCI Thesaurus. Code C162357.

Human IQCK wild-type allele is located in the vicinity of $16 p 12.3$ and is approximately 142

$\mathrm{kb}$ in length. This allele, which encodes IQ domain-containing protein $\mathrm{K}$, plays a role in protein-protein interactions. 